\title{
Erratum to: Unraveling the mechanisms of synapse formation and axon regeneration: the awesome power of $C$. elegans genetics
}

\author{
JIN YiShi \\ Howard Hughes Medical Institute, Section of Neurobiology, Division of Biological Sciences, University of California, \\ San Diego CA 92093, USA
}

\author{
Erratum to: SCIENCE CHINA Life Sciences, November 2015 Vol.58 No.11: 1084-1088 \\ doi: $10.1007 / \mathrm{s} 11427-015-4962-9$
}

In the first paragraph of the manuscript, the name of Charles Harrington was printed in error, should be Charles Sherrington.

The online version of the original article can be found at http://dx.doi.org/10.1007/s11427-015-4962-9

Open Access This article is distributed under the terms of the Creative Commons Attribution License which permits any use, distribution, and reproduction in any medium, provided the original author(s) and source are credited. 